Tersedia online di: http://ejournal-balitbang.kkp.go.id/index.php/bawal
e-mail:bawal.puslitbangkan@ @mail.com
BAWAL wIDYA RISET PERIKANAN TANGKAP
Volume 9 Nomor 2 Agustus 2017
p-ISSN: 1907-8226
e-ISSN: 2502-6410
BAWAL
Nomor Akreditasi: $620 /$ AU2/P2MI-LIPI/03/2015

\title{
PARAMETER POPULASI DAN TINGKAT PENGUSAHAAN RAJUNGAN (Portunus pelagicus) DI PERAIRAN ASAHAN, SELAT MALAKA
}

\section{POPULATION PARAMETERS AND EXPLOITATION RATE OF BLUE SWIMMING CRAB (Portunus pelagicus) IN THE ASAHAN WATERS, MALACCA STRAIT}

\author{
Andina Ramadhani Putri Pane ${ }^{* 1}$, Heri Widiyastuti ${ }^{1}$ dan Ali Suman ${ }^{1}$ \\ ${ }^{1}$ Balai Riset Perikanan Laut, Kompleks Raiser, Jl. Raya Bogor KM. 47 Cibinong, Bogor \\ Teregistrasi I tanggal: 02 Februari 2017; Diterima setelah perbaikan tanggal: 18 September 2017; \\ Disetujui terbit tanggal: 24 Oktober 2017
}

\begin{abstract}
ABSTRAK
Tingginya permintaan pasar terhadap rajungan mengakibatkan aktivitas penangkapannya berlangsung secara intensif. Selat Malaka merupakan salah satu daerah penangkapan rajungan yang penting di Indonesia. Tujuan penelitian ini adalah untuk mengestimasi parameter populasi dan tingkat eksploitasi rajungan (Portunus pelagicus) di perairan Asahan dan sekitarnya. Pengumpulan data bulanan dilakukan pada bulan Juni 2015 sampai dengan Nopember 2016. Hasil penelitian menunjukkan bahwa musim penangkapan berlangsung sepanjang tahun dengan puncak pada bulan Juli dan Oktober, puncak pemijahan terjadi pada bulan Januari dan Agustus. Ukuran lebar karapas pertama kali tertangkap dengan gillnet $\left(\mathrm{L}_{\mathrm{c}}\right)$ dan ukuran pertama kali matang gonad $\left(\mathrm{L}_{\mathrm{m}}\right)$ masing-masing sebesar 109,6 mm dan 104,1 mm. Laju pertumbuhan (K) sebesar 1,38/tahun dan lebar karapas asimtotik $\left(\mathrm{L}_{\infty}\right)$ sebesar 183,10 mm. Laju kematian total (Z) rajungan sebagai 4,31 per tahun, laju kematian karena penangkapan (F) dan laju kematian alami (M) masing-masing 2,96 per tahun dan 1,35 per tahun; laju eksploitasi (E) diestimasi sebesar 0,69. Tingkat pemanfaatan rajungan di perairan Asahan diduga telah melewati optimal, sehingga perlu dilakukan pengelolaan melalui pengurangan jumlah unit gillnet rajungan sebanyak $38 \%$ dari kondisi saat ini.
\end{abstract}

Kata Kunci: Rajungan; parameter populasi; tingkat pengusahaan; Selat Malaka

\section{ABSTRACT}

Blue swimming crab faced intensive fishing pressure due to the high market demand. The Malacca Strait is one of important fishing area for blue swimming crab. The research aims to estimate the population parameters and exploitation rate of blue swimming crab (Portunus pelagicus) in the Asahan and adjacent waters. A monthly data were collected from June 2015 to November 2016 that caught by Gillnet. The results showed that the fishing season takes place throughout the year with peaks in July and October, meanwhile peak of spawning season in January and August. The carapace width at first capture $\left(L_{c}\right)$ and first mature $\left(L_{m}\right)$ were $109.6 \mathrm{~mm}$ and 104.1 $\mathrm{mm}$, respectively. The growth rate $(K)$ was $1.38 /$ year and the asymptotic length $\left(L_{\infty}\right)$ was $183.10 \mathrm{~mm}$. Total mortality rate $(Z)$ was 4.31 per year, fishing mortality rate $(F)$ and natural mortality rate $(M)$ were 2.96 per year and 1.35 per year respectively; Exploitation rate $(E)$ was estimated at 0.69 . It means that the exploitation rate of swimming crab in the Asahan waters found exceed the optimum level, therefore the management measures needs to reduce effort (unit) of gillnet by a $38 \%$ of actual level.

Keywords : Blue swimming crabs; population parameters; exploitation rate; Malacca strait 


\section{PENDAHULUAN}

Perairan Asahan merupakan salah satu daerah di Wilayah Pengelolaan Perikanan Negara Republik Indonesia 571 (WPP NRI 571) Selat Malaka dan Laut Andaman. Sumber daya perikanan di wilayah ini meliputi berbagai jenis ikan termasuk udang dan krustasea lain. Salah satu jenis krustasea penting adalah rajungan (Portunus pelagicus). Selain untuk keperluan konsumsi di dalam negeri, komoditas ini diekspor dalam bentuk beku segar tanpa kulit atau daging rajungan dalam kaleng. Rajungan memiliki rasa daging yang lezat, nilai gizinya pun cukup tinggi sehingga permintaan akan komoditas ini semakin meningkat (Setiyowati, 2016). Nilai ekonomis yang tinggi akan menyebabkan tingginya permintaan dan akan meningkatkan pemanfaatan. Apabila pemanfaatan berlangsung terus-menerus, maka dikhawatirkan akan mengganggu kelestarian sumber daya. Menurut Saputra et al. (2009) intensitas penangkapan perlu dibatasi agar tidak mengarah pada recruitment overfishing, yaitu apabila kegiatan perikanan banyak menangkap ikan-ikan yang masih berumur muda sehiungga tidak memiliki kesempatan untuk bertambah banyak atau bereproduksi.

Menurut Sumiono et al. (2011) daerah penyebaran rajungan di Indonesia sangat luas, terutama terdapat di perairan pantai yang relatif dangkal antara lain : Selat Malaka, pantai timur Sumatera, utara Jawa, Kalimantan Selatan dan Timur, Sulawesi selatan, Sulawesi Tenggara dan Laut Arafura. Daerah Teluk Jakarta dan Cirebon merupakan salah satu penghasil rajungan yang cukup penting di utara Jawa selain Brebes, Rembang dan Selat Madura.

Daerah pendaratan ikan bagi nelayan tradisional yang cukup penting di Selat Malaka selain Tanjungbalai adalah kota Asahan (Kabupaten Asahan). Jenis perikanan yang berkembang selama lima tahun terakhir adalah rajungan terutama jenis Portunus pelagicus yang ditangkap menggunakan jaring rajungan atau jaring insang dasar (bottom gillnet). Data dari Dinas Perikanan dan Kelautan Kabupaten Asahan menunjukkan produksi rajungan pada tahun 2014 sebesar 1300 ton dan meningkat menjadi 1700 ton pada tahun 2015 .

Penangkapan rajungan yang dilakukan secara terus menerus jika tidak disertai dengan upaya pengelolaan, maka akan mengancam kelestarian sumber dayanya. Untuk melakukan pengelolaan perikanan yang rasional diperluan bahan pertimbangan berdasarkan hasil penelitian tentang aspek biologi dan perikanan rajungan. Chu et al. (2012) menyatakan untuk menilai status stok ikan atau mengetahui kondisi sumberdaya ikan yang sedang berjalan di suatu perairan, antara lain perlu dilakukan kajian pertumbuhan, kematian dan rasio potensi pemijahan (spawning potential ratio).
Penelitian tentang rajungan di Selat Malaka masih sangat minim. Penelitian tentang dinamika populasi rajungan dan laju eksploitasi (exploitation rate) dilakukan di Asahan yang merupakan tempat pendaratan rajungan cukup penting di Selat Malaka setelah Tanjungbalai. Tujuan penelitian ini adalah untuk mendapatkan data dan informasi tentang laju pertumbuhan dan kematian rajungan, kematangan gonada, panjang pertama kali tertangkap dan pertama kali matang gonada. Selain itu juga dibahas secara ringkas tentang aspek penangkapan dan tingkat eksploitasi rajungan. Hasil penelitian ini diharapkan dapat menjadi masukan untuk tujuan pengelolaan rajungan secara bertanggungjawab sehingga dapat dimanfaatkan secara berkesinambungan untuk meningkatkan kesejahteraan nelayan di perairan Asahan.

\section{BAHANDANMETODE Pengumpulan Data}

Penelitian rajungan (Portunus pelagicus) dilakukan di Asahan selama bulan Juni 2015 sampai Nopember 2016 melalui sampling berkala (bulanan) dengan bantuan enumerator. Pengumpulan data dan informasi diperoleh melalui gudang (tangkahan) di daerah Pematang Sei Baru, Kecamatan Silau Baru. Lokasi pendaratan ini menjadi tempat sampling karena mempunyai nelayan rajungan yang paling banyak setelah Tanjungbalai di wilayah Selat Malaka. Sebanyak 200 ekor/bulan rajungan (campuran jantan dan betina) dikumpulkan melalui tangkahan terpilih. Karakter biologi yang diamati meliputi ukuran lebar karapas, bobot individu dan tingkat kematangan gonad rajungan betina. Pengukuran lebar karapas dilakukan dengan menggunakan jangka sorong, bobot tubuh diukur dengan timbangan digital. Pembedahan perut (abdomen) dilakukan untuk mengetahui tingkat kematangan gonad rajungan betina, karena rajungan betina yang menghasilkan telur untuk reproduksi. Tingkat kematangan gonad rajungan betina mengacu Sumpton et al. (1994) yang membagi menjadi lima tingkatan, sebagai berikut :

1. Tingkat Kematangan Gonada (TKG) I : belum terlihat tanda-tanda secara makroskopis dari gonad

2. TKG II : gonad immature (belum matang), gonad berwarna putih atau tembus cahaya dengan diameter telur mencapai $0,14 \mathrm{~mm}$.

3. TKG III : gonad maturing, gonad berwarna kuning/ oranye muda, tidak menyebar dalam area hati dengan diameter telur antara $0,15-0,21 \mathrm{~mm}$.

4. TKG IV : gonad mature, gonad berwarna oranye terang, terseber hingga area hati dengan diameter telur antara $0,22-0,40 \mathrm{~mm}$.

5. TKG V : ovigerous, rajungan betina membawa telur yang sudah dibuahi di bagian kaki jalannya (pleopod).

Enumerator juga mencatat data hasil tangkapan harian rajungan dan ikan dari alat tangkap jaring insang tetap (bottom gillnet) yang mendaratkan hasilnya di tangkahan. 


\section{Analisis Data}

Panjang (baca: lebar) karapas pertama kali tertangkap (length at first capture, $\mathrm{L}_{c}$ ) rajungan dengan gillnet dianalisis berdasarkan frekuensi kumulatif ukuran rajungan yang tertangkap. Dibuat grafik hubungan antara distribusi kelas lebar karapas (sumbu x) dengan persentase kumulatif jumlah rajungan (sumbu y), sehingga terbentuk kurva berbentuk S (sigmoid). Nilai $\mathrm{L}_{c}$ dinyatakan sebagai titik potong antara kurva 50\% frekuensi kumulatif dengan nilai lebar karapas (Saputra, 2009).

Ukuran pertama kali matang gonad (length at first maturity, $\mathrm{L}_{\mathrm{m}}$ ) rajungan betina diperoleh dari fungsi logistik dengan memasukkan rata-rata pertama kali matang gonad $\left(\mathrm{P}_{\mathrm{Lm}}\right)$ dan kelas lebar karapas melalui persamaan sebagai berikut (King, 1995) :

$$
P_{C L M}=\frac{1}{1+\exp (a C l+b)}
$$

Dimana:

$$
\begin{array}{ll}
\mathrm{P}_{\mathrm{CLm}} & =\text { Ukuran pertama kali matang gonad } \\
\mathrm{Cl} & =\text { lebar karapas }(\mathrm{mm}) \\
\mathrm{a} & =\text { intercept } \\
\mathrm{b} & =\text { slope }
\end{array}
$$

Kajian parameter populasi menggunakan model analitik berdasarkan ukuran rajungan (Spare \& Venema, 1992). Parameter pertumbuhan dari Von Bertalanffy yaitu lebar karapas asimptotik $\left(\mathrm{L}_{\infty}\right)$ dan koefisien pertumbuhan $(\mathrm{K})$ diduga melalui program ELEFAN I (Gayanilo et al., 2005). Nilai $\mathrm{t}_{\mathrm{o}}$ (umur pada saat panjang $=0$ ) diduga berdasarkan persamaan Pauly (1983) yaitu:

$\log \left(-t_{0}\right)=(-0,3922)-0,2752 \log L_{\infty}-1,038 \log \mathrm{K}$

Kematian alamiah (M) diduga dengan rumus empiris Pauly (1983). Berdasarkan pengamatan empirisnya, dijelaskan ada pengaruh suhu rata-rata perairan $(=\mathrm{T})$ terhadap laju mortalitas sesuai dengan persamaan berikut:

$\log M=(-0,0066)-0,279 \log L_{\infty}+0,6543 \log K+0,4634$ $\log \mathrm{T}$

\section{Dimana :}

$\mathrm{M}$ = laju kematian alamiah

$\mathrm{L}_{\infty}$ = panjang (lebar) karapas asimtotik

$\mathrm{K}$ = laju pertumbuhan

$\mathrm{T}=$ suhu rata-rata perairan $\left(\mathrm{di}\right.$ Asahan $\left.=29^{\circ} \mathrm{C}\right)$

Nilai Mortalitas total (Z) diduga dengan metode kurva konversi hasil tangkapan dengan panjang (length converted catch curve) yang dianalisis dengan paket program FiSAT II (Pauly, 1983; Gayanilo et al., 2005).
Penghitungan laju kematian karena penangkapan (F) didasarkan pada selisih antara laju kematian total $(\mathrm{Z})$ dengan laju kematian alami (M). Penghitungan tingkat pemanfaatan $E$ diperoleh dari perbandingan antara nilai $F$ dengan Z, menggunakan persamaan: E=F/Z(Sparre \& Venema, 1999).

\section{HASIL DAN BAHASAN Hasil}

\section{Musim Penangkapan dan Musim Pemijahan}

Penangkapan rajungan dilakukan nelayan di pesisir Kabupaten Asahan dengan menggunakan jaring rajungan (jaring insang dasar, bottom gillnet) yang dioperasikan oleh dua orang nelayan menggunakan perahu berukuran $<3 \mathrm{GT}$ dengan mesin $10 \mathrm{PK}$. Biasanya dalam satu perahu membawa 3 pis (piece) jaring. Aktivitas penangkapan dilakukan dalam skala harian (one day fishing), berangkat sekitar pukul 6.00 pagi dan kembali pukul 14.00 siang, dilakukan pada jarak antara 1-2 mil dari pantai. Pencatatan data pendaratan rajungan di Asahan, menunjukkan produksi selama Januari - Nopember 2016 terdapat peningkatan pada Juli sampai dengan Oktober, demikian pula laju tangkap dengan jaring insang, sedangkan data upaya (jumlah unit jaring insang) relatif tetap (Tabel 1). Puncak musim penangkapan yang ditandai dengan laju tangkap tinggi (antara 7,2-7,4 kg/unit/hari) berlangsung pada bulan Agustus dan Oktober.

Pemijahan rajungan betina dapat diketahui berdasarkan kematangan gonadnya, dimana musim pemijahan diduga bersamaan dengan musim matang gonad. Rajungan belum matang gonad (immature stage) terdapat pada tingkat kematangan gonad (TKG) I dan II, sedangkan matang gonad (mature stage) pada TKG III dan IV. Hasil pengamatan menunjukkan puncak matang gonad terjadi pada bulan Januari dan Agustus bersamaan dengan puncak musim pemijahan (Gambar 1).

\section{Ukuran Rajungan Pertama Kali Tertangkap $\left(L_{c}\right)$ dan Pertama Kali Matang Gonad $\left(L_{m}\right)$}

Rajungan yang tertangkap di perairan Asahan mempunyai lebar karapas antara 50 - 165 mm dengan modus pada kelas $100-110 \mathrm{~mm}$. Rajungan jantan dan betina dominan tertangkap masing-masing pada lebar karapas antara 100 - 110 mm dan 90 - 105 mm. Distribusi frekuensi lebar karapas rajungan disertakan pada Gambar 2. Ukuran rajungan pertama kali tertangkap $\left(L_{c}\right)$ dan ukuran pertama kali matang gonad $\left(\mathrm{L}_{\mathrm{m}}\right)$ dinyatakan dalam proporsi $50 \%$ dari populasi yang diamati. Nilai $\mathrm{L}_{\mathrm{c}}$ dan $\mathrm{L}_{\mathrm{m}}$ ini diperoleh dengan menggunakan fungsi logistik. Diperoleh nilai $\mathrm{L}_{\mathrm{c}}$ sebesar 109,6 mm dan $\mathrm{L}_{\mathrm{m}}$ sebesar 104,1 mm (Gambar 3 dan 4). Dengan demikian ukuran rajungan yang tertangkap umumnya lebih besar dibanding ukuran pertama matang $\operatorname{gonad}\left(\mathrm{L}_{\mathrm{m}}<\mathrm{L}_{\mathrm{c}}\right)$. 
Tabel 1. Hasil tangkapan, upaya dan hasil per unit upaya rajungan dengan gill net di perairan Asahan, 2016 Table 1. Catch, effort and catch per effort of blue swimming crabs caught by gill net in Asahan waters, 2016

\begin{tabular}{lccc}
\hline $\begin{array}{c}\text { Bulan / } \\
\text { Month }\end{array}$ & Upaya (Unit)/ Effort & $\begin{array}{c}\text { Produksi (Kg)/ } \\
\text { Production }\end{array}$ & $\begin{array}{c}\text { Hasil per unit upaya (Kg) / } \\
\text { Catch per unit of effort }\end{array}$ \\
\hline Januari & 464 & 2349,9 & 5,1 \\
Februari & 409 & 2170,4 & 5,3 \\
Maret & 386 & 2210,6 & 5,7 \\
April & 427 & 1986,7 & 4,7 \\
Mei & 443 & 2416,4 & 5,5 \\
Juni & 505 & 3030,9 & 6,0 \\
Juli & 406 & 3011,8 & 7,4 \\
Agustus & 681 & 4265,9 & 6,3 \\
September & 606 & 3780,4 & 6,2 \\
Oktober & 583 & 4231,3 & 7,3 \\
Nopember & 667 & 3095,1 & 4,6 \\
\hline
\end{tabular}

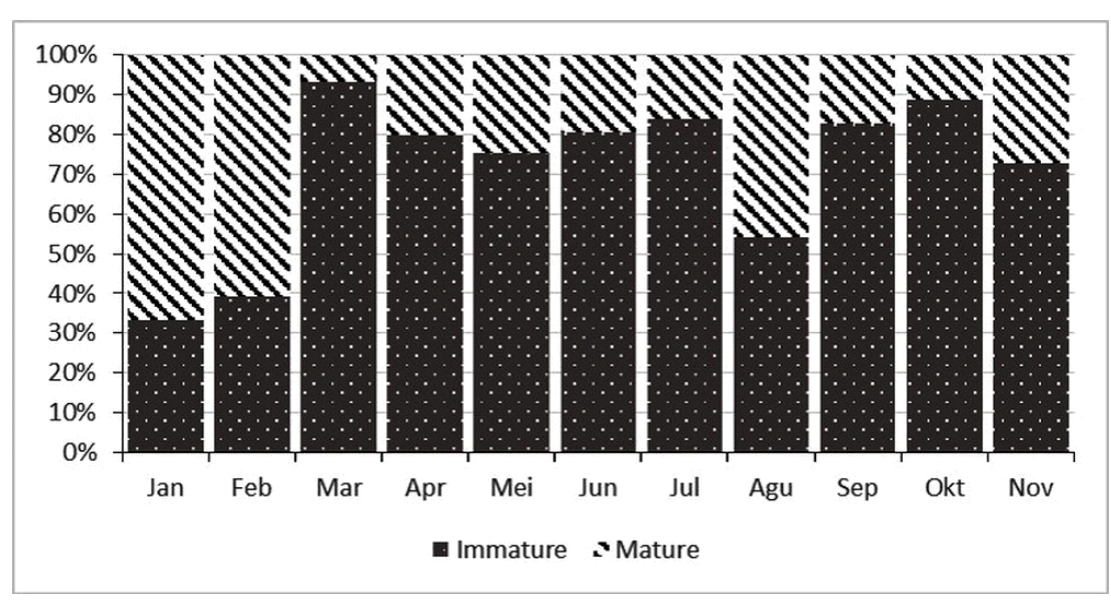

Gambar 1. Tingkat kematangan gonad rajungan betina di perairan Asahan, 2016.

Figure 1. Gonad maturity stage of blue swimming crabs female in Asahan waters, 2016.

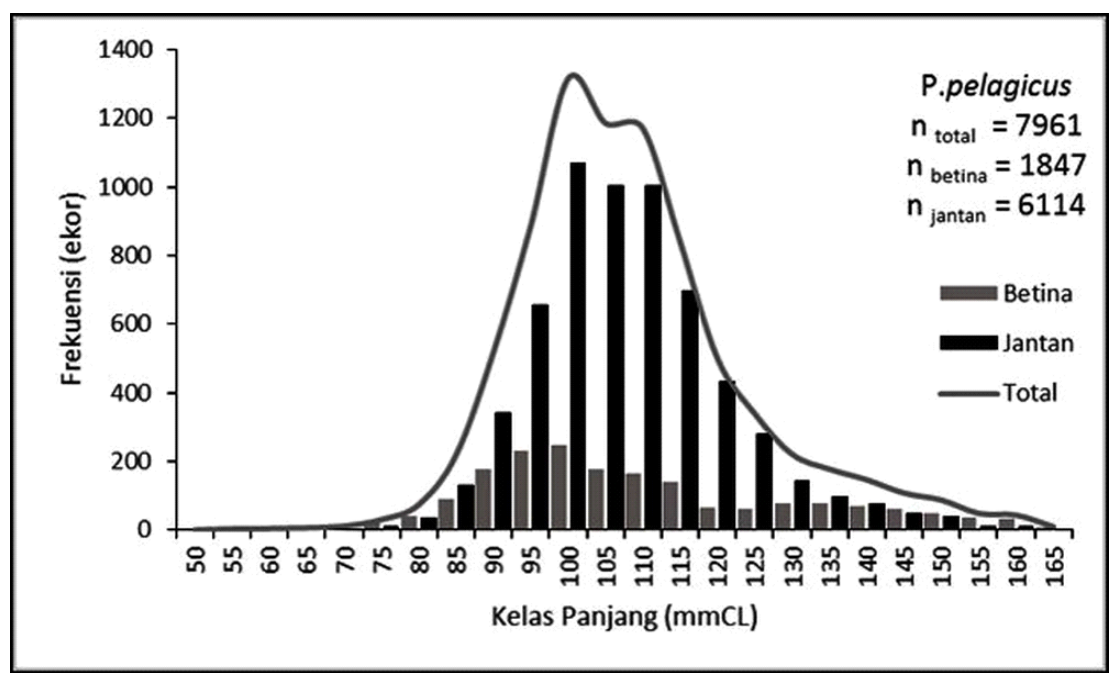

Gambar 2. Distribusi frekuensi lebar karapas rajungan di perairan Asahan, 2015 - 2016.

Figure 2. Carapace width frequency ditribution of blue swimming crabs in Asahan waters, 2015 - 2016. 


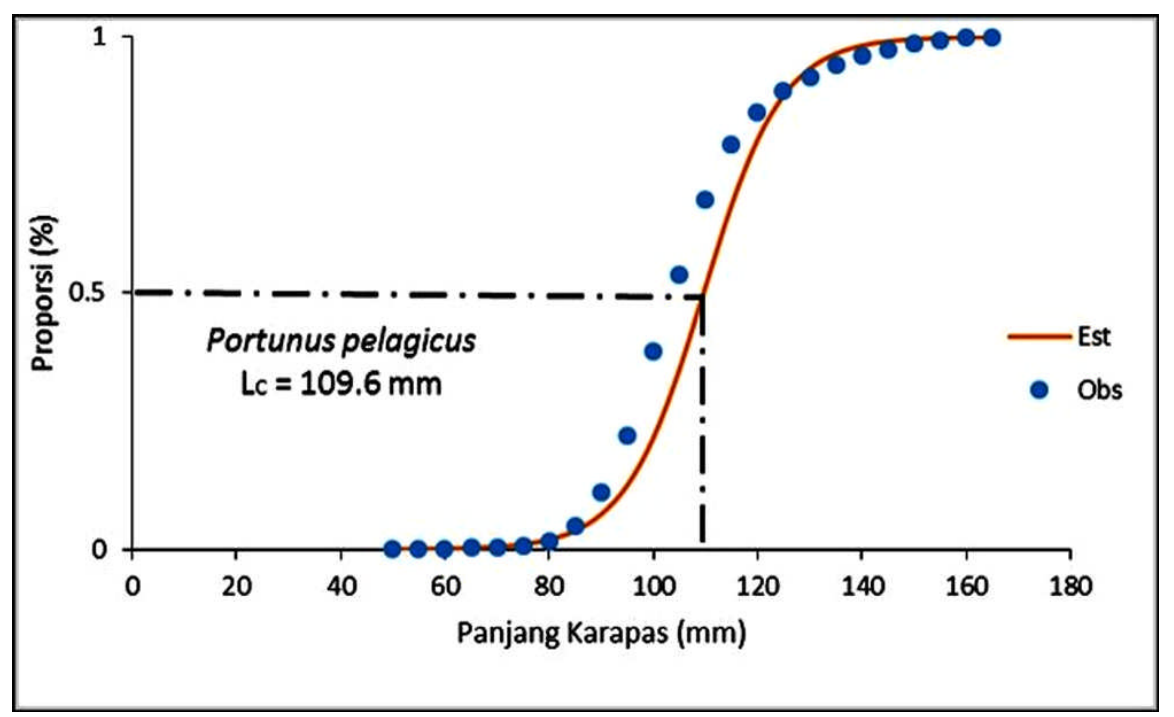

Gambar 3. Frekuensi kumulatif dari distribusi frekuensi lebar karapas rajungan di perairan Asahan.

Figure 3. Cumulative frequency of the carapace width frequency distribution of blue swimming crabs in Asahan waters.

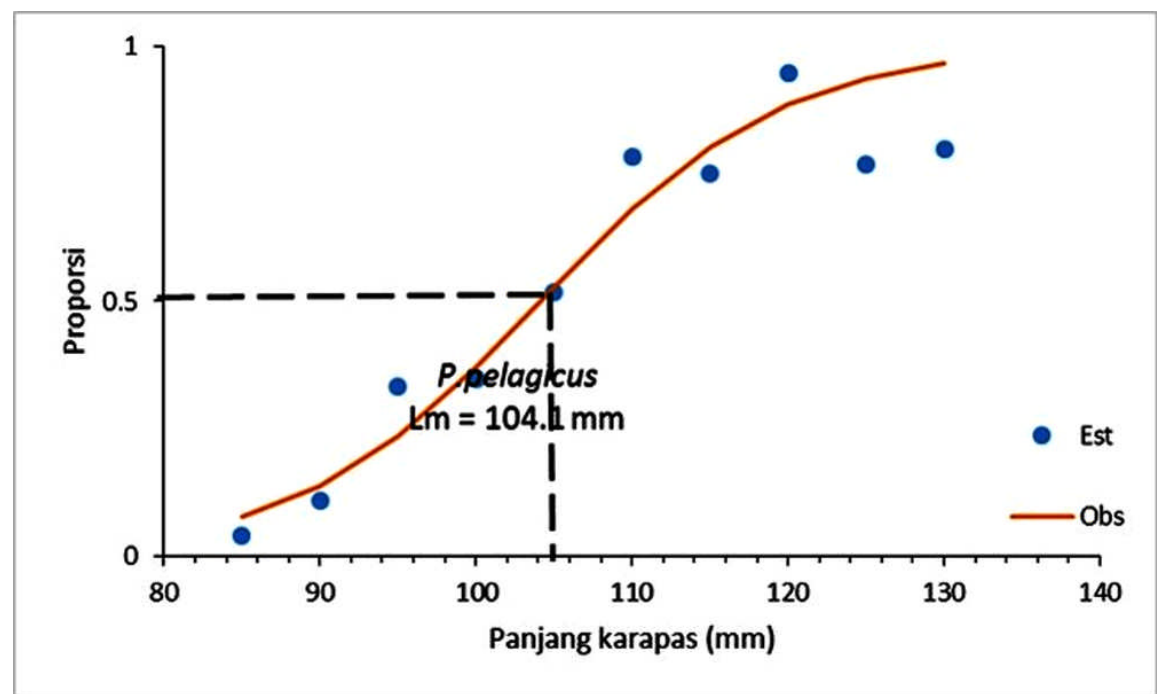

Gambar4. Kurva logistik hubungan antara proporsi matang gonada dengan lebar karapas rajungan di perairan Asahan.

Figure 4. A logistic relationship between proportion of gonad mature and carapace width of blue swimming crabs in Asahan waters.

\section{Pertumbuhan, Laju Kematian dan Laju pengusahaan}

Dengan merunut data menggunakan program ELEFAN terhadap frekuensi lebar karapas dari bulan ke bulan diperoleh 2 kelompok umur (kohor) rajungan yang tertangkap (Gambar 5). Kecuali itu, diperoleh laju pertumbuhan $(\mathrm{K})$ rajungan di perairan Asahan adalah 1,38/ tahun dan lebar karapas asimptotik (L,) adalah 183,10mm. Umur rajungan saat panjang $0\left(\mathrm{t}_{0}\right)$ sebesar $-0,064$ tahun. Dengan demikian persamaan pertumbuhan von Bertalanffy untuk rajungan sebagai $\mathrm{Lt}=183,10\left[1-\mathrm{e}^{-1,38(t+0,064)}\right]$.

Dengan menggunakan parameter pertumbuhan rajungan ( $\mathrm{K}$ dan $\mathrm{L}_{\text {,) }}$ ) yang diperoleh dan menjadikannya sebagai bahan masukan untuk membuat kurva hasil tangkap dengan program ELEFAN 1, diperoleh estimasi nilai kematian total $(\mathrm{Z})$ rajungan sebesar 4,31/tahun (Gambar 6). Nilai dugaan laju kematian alamiah (M) sebesar 1,35/ tahun dan laju kematian karena penangkapan (F) sebesar 2,96/tahun.

Dengan menggunakan nilai $\mathrm{F}$ dan $\mathrm{Z}$ tersebut, diperoleh laju pengusahaan (E) rajungan di perairan Asahan sebesar 0,69/tahun. Laju pengusahaan tersebut mengindikasikan bahwa tingkat pemanfaatan rajungan di Asahan sudah melebihi potensi lestarinya (overfishing). 


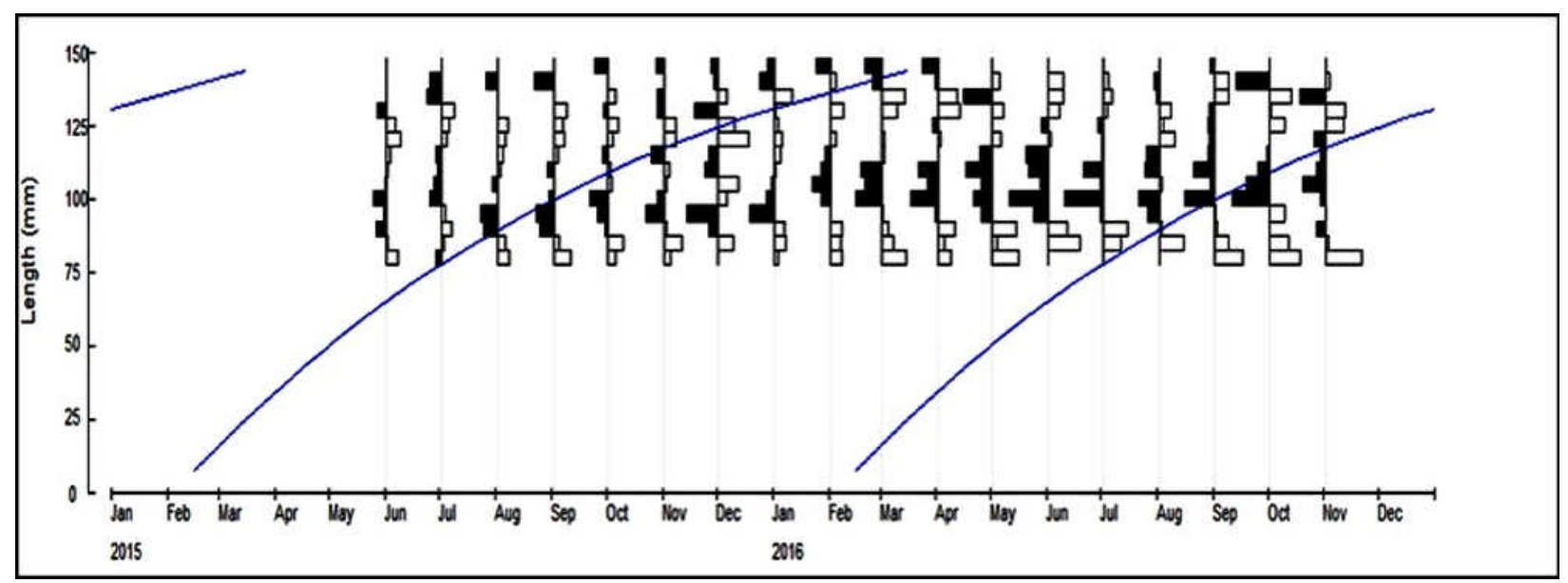

Gambar 5. Histogram frekuensi bulanan lebar karapas rajungan di perairan Asahan, diperoleh garis 2 kelompok umur. Figure 5. Carapace width-frequency histograms for blue swimming crabs in Asahan waters. The progession of two cohorts is sugested by the curves.

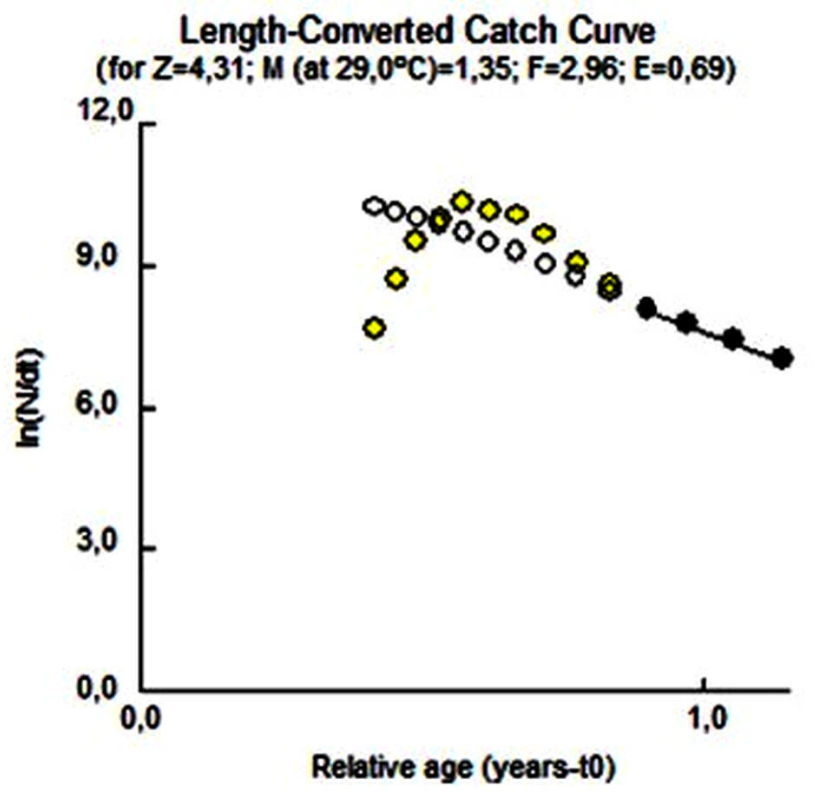

Gambar6. Nilai kematian total $(Z)$ sebagai kemiringan grafik logaritma jumlah individu terhadap umur rajungan di perairan Asahan.

Figure 6. The value of total mortality $(Z)$ as a slope of catch curve, natural logarithms of the number individual againts age of blue swimming crab in Asahan waters.

\section{Bahasan}

Penangkapan rajungan di perairan Asahan menggunakan gillnet dasar (lokal: jaring rajungan). Pemakaian alat ini disesuaikan dengan tujuan penangkapan bahwa rajungan umumnya hidup di dasar perairan pada daerah pantai yang relatif dangkal (Barus et al., 1987). Diperoleh ukuran rajungan yang tertangkap pada lebar karapas antara 50 - $165 \mathrm{~mm}$. Ukuran ini masih lebih besar daripada rajungan yang tertangkap di perairan Kota Baru yaitu antara 70-85 mm (Wedjatmiko et al., 2012).

Perbedaan rentang kisaran lebar karapas pada lokasi yang berbeda salah satunya dipengaruhi oleh alat tangkap yang digunakan. Semakin selektif alat tangkap yang digunakan, ukuran rajungan yang tertangkap akan semakin besar, sehingga rentang kisaran lebar karapasnya akan semakin sempit. Hal ini berpengaruh terhadap ukuran pertama kali tertangkap $\left(\mathrm{L}_{\mathrm{c}}\right)$. Semakin besar ukuran mata jaring, maka akan semakin besar pula selektivitas alat tangkap tersebut sehingga mengurangi kemungkinan rajungan muda yang berukuran kecil tertangkap. Nilai $\mathrm{L}_{\mathrm{c}}$ yang besar menunjukkan kondisi stok sumber daya rajungan di perairan tersebut masih baik.

Musim penangkapan di perairan Asahan berlangsung sekitar bulan Juli dan Oktober. Di Teluk Jakarta puncak penangkapan rajungan dengan alat tangkap bubu dan 
jaring rajungan adalah bulan Juni dan Juli, musim penangkapan berlangsung sepanjang tahun (Nuraini et al., 2009). Pola musim penangkapan ini diduga berkaitan dengan pola musiman angin di Laut Jawa dan Selat Malaka.

Rajungan yang matang gonad paling banyak ditemukan pada bulan Januari dan Agustus yang diduga saat itu merupakan puncak musim pemijahan rajungan di perairan Asahan. Menurut Batoy et al. (1987), Dixon \& Hooper (2010) dalam Ernawati et al. (2014) rajungan jenis $P$. pelagicus di perairan tropis dapat memijah sepanjang tahun. Peneliti Zairion et al. (2014) menyatakan rajungan dalam kondisi membawa telur di kaki jalannya (BEF, barried egg females atau ovigerous female) ditemukan sepanjang tahun di pesisir Lampung Timur. Hal ini dapat dinyatakan bahwa pola musim pemijahan bersifat kontinu-musiman (seasonal continiues). Di perairan Teluk Lasongko, Sulawesi Selatan, rajungan betina yang mengerami telur (barrier egg) banyak ditemukan pada bulan November (Hamid et al., 2015). Musim pemijahan rajungan di perairan Pati terjadi pada bulan Oktober - Februari (Ernawati et al, 2014); di Lampung Timur terjadi pada bulan Mei dan September (Zairion et al., 2014) ; di Tapanuli Tengah pada bulan Mei (Ramadhani \& Kembaren, 2014).

Perbedaan musim pemijahan setiap perairan dapat disebabkan karena perbedaan kesuburan perairan. Kesuburan perairan erat berkaitan dengan ukuran dan bobot tubuh rajungan. Rajungan yang bertelur tergantung pada ukuran tubuh (lebar karapas atau bobot tubuh). Menurut Lestang et al. (2003) dan Johnson et al. (2010) bahwa rajungan dalam satu musim pemijahan dapat mengeluarkan telur lebih dari satu tahap, tergantung pada ukuran tubuhnya.

Perubahan rata-rata ukuran rajungan yang tertangkap dari tahun ke tahun harus dievaluasi untuk melihat kemungkinan terjadinya penurunan ukuran rata-rata tertangkap sebagai indikasi telah terjadi over fishing (Budiarto et al., 2015). Selanjutnya untuk tujuan pengelolaan sumberdaya ikan, penetapan length of first capture $\left(\mathrm{L}_{\mathrm{c}}\right)$ dikaitkan dengan length of first mature $\left(\mathrm{L}_{\mathrm{m}}\right)$ yang diperuntukkan untuk menghitung jumlah penambahan individu baru (Prisantoso, 2010).

Hasil penelitian rajungan di perairan Asahan diperoleh ukuran lebar karapas pada pertama kali tertangkap $\left(\mathrm{L}_{\mathrm{c}}=\right.$ $109,6 \mathrm{~mm}$ ) lebih besar dari ukuran pertama kali matang go$\operatorname{nad}\left(\mathrm{L}_{\mathrm{m}}=104,1 \mathrm{~mm}\right)$ pada individu betina. Pada kondisi ini, maka dapat mendukung kelestarian populasi rajungan, dimana rajungan betina yang tertangkap paling tidak sudah pernah melakukan pemijahan atau diberi kesempatan untuk menambah individu baru. Fenomena yang sama, dimana nilai $\mathrm{L}_{\mathrm{c}}>\mathrm{L}_{\mathrm{m}}$ juga diperoleh pada populasi rajungan di perairan Tapanuli Tengah (Ramadhani \& Kembaren, 2014), di Belitung (Ernawati et al., 2015) dan di perairan Pati
(Ernawati et al., 2014). Hasil yang berbeda, didapat dari penelitian rajungan di perairan Labuhan Maringgai dimana $\mathrm{L}_{\mathrm{c}}(=109,72 \mathrm{~mm})<\mathrm{L}_{\mathrm{m}}(=113,50 \mathrm{~mm})($ Damora et al., 2012$)$. Demikian pula di perairan Demak diperoleh nilai $\mathrm{L}_{\mathrm{c}}(=122$ $\mathrm{mm})<\mathrm{L}_{\mathrm{m}}(=136 \mathrm{~mm}$ ) (Nigrum et al., 2015). Pemanfaatan rajungan di kedua perairan ini dapat mengarah kepada recruitment over fishing dimana tidak memberi kesempatan pada induk rajungan melakukan pemijahan sebelum ditangkap.

Dengan tidak membedakan jenis kelaminnya, analisis parameter pertumbuhan rajungan di perairan Asahan diperoleh laju pertumbuhan $(\mathrm{K})$ sebesar 1,38/tahun dan lebar karapas asimptotik $\left(\mathrm{L}_{,}\right)$adalah $183,10 \mathrm{~mm}$. Peneliti lain, memperoleh parameter pertumbuhan rajungan di Teluk Lasongko (Buton Tengah) $\mathrm{K}=0,68 /$ tahun untuk jenis kelamin betina dan $\mathrm{K}=0,98 /$ tahun untuk betina (Hamid \& Wardiatno, 2015); di perairan Bone diperoleh nilai $\mathrm{K}=1$,27/ tahun untuk jantan dan $\mathrm{K}=1,08 /$ tahun untuk betina (Kembaren et al., 2012); di Mayangan (Subang) diperoleh nilai $\mathrm{K}=0,97 /$ tahun untuk jantan dan nilai $\mathrm{K}=0,8 /$ tahun untuk betina (Hermanto, 2004); dan Belitung nilai $\mathrm{K}=1,02$ / tahun (Ernawati et al.,2015).

Nilai laju pertumbuhan berhubungan dengan umur rajungan (Saprre \& Venema, 1999). Laju pertumbuhan yang cepat (umumnya $K>1$ ) menunjukkan umur yang pendek atau mortalitas tinggi yang disebabkan oleh penangkapan maupun faktor lingkungan.

Nilai laju kematian alamiah (M) rajungan di perairan Asahan terlihat lebih rendah dibanding laju kematian karena penangkapan (F). Maka rajungan lebih banyak tertangkap daripada mengalami kematian alamiah. Hutan mangrove yang terus dirusak menjadi salah satu penyebab utama menurunnya kualitas lingkungan perairan dan mengakibatkan pada peningkatan laju kematian alamiah rajungan di perairan ini. Untuk penangkapan sendiri dapat dilakukan dengan mudah karena rajungan mengalami beberapa fase dalam siklus hidup yaitu fase larva dan fase pemijahan berada di laut terbuka (ô̂-shore) dan fase juvenil sampai dewasa berada di perairan pantai (in-shore) seperti muara dan estuaria (Kangas,2000). Pembatasan penangkapan perlu dilakukan mengingat siklus hidup tersebut yang menyebabkan rajungan tersebar diperairan pantai.

Dengan memperhatikan nilai kematian karena penangkapan $(\mathrm{F}=2,96 /$ tahun $)$ dan kematian total $(\mathrm{Z}=4,31$ / tahun), diperoleh nilai laju pengusahaan (E) rajungan di perairan Asahan sebesar 0,69/tahun. Berdasarkan kriteria dari Pauly et al. (1984) yang menyatakan bahwa laju pengusahaan yang rasional dan lestari di suatu perairan berada pada nilai $\mathrm{E}<0,5$ atau paling tinggi pada $\mathrm{E}=0,5(100$ $\%)$, maka laju pengusahaan rajungan di perairan Asahan telah melebihi nilai optimalnya (mencapai 138\%). Apabila 
kondisi ini terus dibiarkan tanpa dilakukan upaya pengelolaan rajungan, maka dapat diduga dalam jangka panjang sumber daya rajungan akan terancam kelestariannya. Salah satu upaya yang dapat dilakukan yaitu pembatasan penangkapan dengan melakukan pengurangan upaya (jumlah alat tangkap/gillnet) sebanyak $38 \%$ dari jumlah gillnet saat ini. Upaya lain adalah penghentian penangkapan (stop fishing) saat musim pemijahan.

\section{KESIMPULAN}

Penelitian parameter populasi rajungan (Portunus pelagicus) di perairan Asahan diperoleh selang ukuran lebar karapas antara 50 - 165 mm dengan modus pada kelas $100-110 \mathrm{~mm}$. Musim pemijahan rajungan betina berlangsung pada bulan Januari dan Agustus, Ukuran pertama kali tertangkap dengan gillnet lebih besar $\left(\mathrm{L}_{\mathrm{c}}=\right.$ $109,6 \mathrm{~mm})$ dari ukuran pertama kali matang gonad $\left(\mathrm{L}_{\mathrm{m}}=\right.$ 104,1 mm). Populasi rajungan memiliki laju pertumbuhan yang cepat $(K=1,38 /$ tahun $)$ disertai dengan kematian karena penangkapan ( $\mathrm{F}=2,96 /$ tahun$)$ dan kematian total $(\mathrm{Z}=4,31$ / tahun) yang cukup tinggi. Tingkat pengusahaan pada saat ini sudah melebihi tingkat optimalnya $(E=0,69)$. Untuk keberlanjutan usahanya disarankan pengurangan upaya penangkapan melalui pengurangan jumlah unit gillnet minimal sebanyak $38 \%$ dari kondisi saat ini. Kecuali itu, dapat dilakukan pelarangan menangkap rajungan (closing sesason) pada bulan Januari dan Agustus bersamaan dengan puncak musim pemijahan.

\section{PERSANTUNAN}

Tulisan ini merupakan sebagian hasil dari "Penelitian Karakteristik Biologi Perikanan, Habitat Sumberdaya, dan Potensi Produksi Sumberdaya Ikan di WPP 571 Selat Malaka” Tahun Anggaran 2015 - 2016 pada Balai Penelitian Perikanan Laut, Jakarta. Penulis mengucapkan terima kasih kepada Muhammmad Taufik, M.Si dan Drs. Suwarso, M.Si sebagai Penanggung jawab kegiatan penelitian WPP 571 Tahun 2015 dan 2016.

\section{DAFTAR PUSTAKA}

Barus, H. R., Suwarso., \& Priyadi, H. (1987). Penangkapan Rajungan (Portunus pelagicus Linn.) dengan Jaring Insang Monofilamin di Daerah Perairan Panimbang, Jawa Barat. Jurnal Penelitian Perikanan Laut. 41, 19-28.

Budiarto, A., Adrianto, L., \& Kamal, M. M. (2015). Status Pengelolaan Perikanan Rajungan (Portunus pelagicus) dengan Pendekatan Ekosistem di Laut Jawa (WPP RI 712). J.Kebijak.Perik.Ind. 7(1), 9-24.
Chu, J., Anderson, J.L., \& Anderson, C.M. (2012). Evaluation of New Fishery Performance Indicators (FPIs) : A case study of the Blue Swimming Crab Fisheries in Indonesia and Philippines. Agric. and Rural Dev. Discussion Paper 52. The World Bank. Washington,DC : 7-8

Damora, A., E. Nurdin, \& R. Ramadhani. (2012). Pengusahaan dan Biologi Rajungan (Portunus pelagicus) di Labuhan Maringgai, Lampung Timur. Status Pemanfaatan Sumberdaya Ikan di Perairan Laut Jawa. Balai Penelitian Perikanan Laut. Pusat Penelitian Pengelolaan Perikanan dan Konservasi Sumberdaya Ikan. Badan Penelitian dan Pengembangan Kelautan dan Perikanan. Kementerian Kelautan dan Perikanan. 45-65.

Damora, A \& Wedjatmiko. (2012). Dinamika Populasi Rajungan (Portunus pelagicus Linn.) di Perairan Kota Baru, Kalimantan Selatan. Prosiding Seminar Nasional Perikanan Tangkap. Penguatan Pengelolaan Sumber Daya Ikan Menuju Ekonomi Biru Industrialisasi Perikanan Tangkap. 333-343.

de Lestang, S., Hall, N,G \& Potter, I.C. (2003). Reproductive biology of the blue swimmer crab (Portunus pelagicus, Decapoda: Portunidae) in five bodies of water on the west coast of Australia. Fish. Bull. 101. 745-757.

Ernawati, T., Boer, M., \& Yonvitner. (2014). Biologi Populasi Rajungan (Portunus pelagicus) di Perairan Sekitar Wilayah Pati, Jawa Tengah. Bawal. 6(1), 31-40.

Ernawati, T., Kembaren,D.D., \& Wagiyo, K. (2015). Penentuan Status Stok Sumberdaya Rajungan (Portunus pelagicus Linnaeus, 1758) dengan Metode Spawning Potential Ratio di Perairan Sekitar Belitung. J.Lit.Perik.Ind. 21(2), 63-70.

Ernawati, T., Wedjatmiko., \& Suman, A. (2015). Kajian Parameter dan Tingkat Pemanfaatan Rajungan (Portunus pelagicus Linnaeus, 1758) di Perairan Pati dan Sekitarnya. J.Lit.Perik.Ind. 21(3), 169-176.

Gayanilo, F.C.Jr., Sparre, P., \& Pauly, D. (2005). FAOICLARM Stock Assessment Tools II (FISAT II). Revised version. User's guide. FAO Computerized Information Series (Fisheries) No. 8. Revised Version. FAO Rome.

Hamid, A., Wardiatno, Y, Batu, D.T.F.L., \& Riani, E (2015). Fekunditas dan Tingkat Kematangan Gonad Rajungan (Portunus pelagicus) Betina Mengerami Telur di Teluk Lasongko, Sulawesi Tenggara. Bawal. 7(1), 43-50. 
Hamid, A. \& Wardiatno,Y. (2015). Population Dynamics of the Blue Swimming Crab (Portunus pelagicus Linnaeus, 1758) in Lasongko Bay, Central Buton, Indonesia. AACL Bioflux. 8(5), 729-739.

Hermanto, D, T. (2004). Studi Pertumbuhan dan Beberapa Aspek Reproduksi Rajungan (Portunus pelagicus) di Perairan Mayangan Kabupaten Subang, Jawa Barat. Skripsi. Departemen Manajemen Sumberdaya Perairan. Fakultas Perikanan dan Kelautan. Institut Pertanian Bogor. Tidak dipublikasikan.

Johnson, D. D., Charles,G.A \& Macbeth,W.G (2010). Reproductive biology of Portunus pelagicus in a South-East Australian estuary. Journal of Crustacean Biology. 30(2): 200-205. DOl: 10.1651/08-3076.1

Kangas, M. I. (2000). Synopsis of the Biology and Exploitation of the Blue Swimming Crab,Portunus pelagicus Linnaeus, in Western Australia. Fisheries Research Report . No.121. http://www.ûsh.wa.gov.au.

Kembaren, D, D., Ernawati,T \& Suprapto. (2012). Biologi dan Dinamika Populasi Rajungan (Portunus pelagicus) di Perairan Bone dan Sekitarnya. Jurnal Penelitian Perikanan Indonesia. 18(4), 273-281.

King, M. (1995). Fisheries Biology, Assessment and Management. United Kingdom. Fishing News Books. $341 \mathrm{pp}$.

Ningrum, V, P., Ghofar,A \& Ain,C. (2015). Beberapa Aspek Biologi Perikanan Rajungan (Portunus pelagicus) di Perairan Betahwalang dan Sekitarnya. Jurnal Saintek Indonesia. 11(1), 62-71.

Nuraini, S., Prihatiningsih \& Hartati,S.T. (2009). Parameter Populasi dan Selektivitas Rajungan (Portunus pelagicus Linnaeus) yang Tertangkap dengan Beberapa Jenis Alat Tangkap di Teluk Jakarta. J.Lit.Perik.Ind. 15(4), 287-295.

Pamungkas, A. S. (2013). Kajian Stok Rajungan (Portunus pelagicus) dengan Analisis Frekuensi Ukuran di Perairan Pesisir Lampung Timur. Departemen Manajemen Sumberdaya Perairan. Fakultas Perikanan dan Ilmu Kelautan. Institut Pertanian Bogor. Skripsi. Tidak diterbitkan.

Pauly, D. (1983). A Selection of a simpel methods for the assessment of the tropical fish stock. FAO Fish. Circ. 254. Roma. $52 \mathrm{pp}$.
Prisantoso, B. I. (2010). Alternatif Langkah Pengelolaan Sumber Daya Perikanan. Jurnal Kebijakan Perikanan Indonesia. 2(2), 121-129.

Ramadhani, R \& Kembaren,D.D. (2014). Beberapa Aspek Biologi Rajungan Batik (Portunus pelagicus) di Perairan Kabupaten Tapanuli Tengah. Status Pemanfaatan Sumberdaya Ikan di Samudera Hindia (WPP 572, 573) dan Samudera Pasifik (WPP 711). Ref Grafika. 111-121.

Saputra, S.W., Sukimin,S. Boer, Affandi, R \& Monintja,D.R. (2005). Aspek Reproduksi dan Daerah Pemijahan Udang Jari (Metapenaeus elegans De Man, 1907) di Laguna Sagara Anakan Cilacap Jawa Tengah. J. Ilmu Kelautan. 10 (1), 41-49.

Saputra, S. W., Soedarsono,P. \& Sulistyawati,G.A. 2009. Beberapa Aspek Biologi Ikan Kuniran (Upeneus spp.) di Perairan Demak. Jurnal Saintek Perikanan. 5(1):16.

Setiyowati, D. (2016). Kajian Stok Rajungan (Portunus pelagicus) di Perairan Laut Jawa, Kabupaten Jepara. Jurnal Disprotek. Universitas Islam Nahdatul Ulama. 7(1) :84 -97. ISSN : 2088-6500.

Sparre, P., \& Venema, S.C. (1992). Introduction to tropical fish stock assessment (p.376). Rome: FAO Fisheries Technical Paper

Sparre, P \& Venema, S. (1999). Introduction tp Tropical Fish Stock Assesment. (Introduksi Pengkajian Stok Ikan Tropis, alih bahasa : Pusat Penelitian dan Pengembangan Perikanan). Buku 1 : Manual. Badan Penelitian dan Pengembangan Perikanan. Jakarta. 438 p.

Sumiono,B., Wagiyo,K., Duranta,K \& Prihartiningsih. (2011). Aspek Penangkapan dan Biologi Rajungan (Portunus pelagicus Linn.) di Perairan Teluk Jakarta dalam Suman, A., Wudianto \& Sumiono,B. (Eds.): Sumberdaya Ikan di Perairan Teluk Jakarta dan Alternatif Pengelolaannya. Balai Penelitian Perikanan Laut. Badan Litbang Kelautan dan Perikanan: 107-126.

Sumpton,W.D., M.A. Potter \& G.S.Smith. (1994). Reproduction and Growth of the Commercial Sand Crab, Portunus pelagicus (Linn.) in Moreton Bay, Queensland. Asian Fish.Sci. (7), 103-113. 
Wedjatmiko,. Damora, A \& Lestari, P. (2012). Aspek Penangkapan dan Biologi Rajungan (Portunus pelagicus Linn) di Perairan Kota Baru. Prosiding Seminar Nasional Perikanan Tangkap. Penguatan Pengelolaan Sumber Daya Ikan Menuju Ekonomi Biru Industrialisasi Perikanan Tangkap. Kementerian Kelautan dan Perikanan. 487 - 498.
Zairion, Wardiatno, Y., Fahrudin, A. \& Boer, M. (2014). Distribusi Spasio - Temporal Populasi Rajungan (Portunus pelagicus) Betina Mengerami Telur di Perairan Pesisir Lampung Timur. Bawal. 6(2), 95-102. 